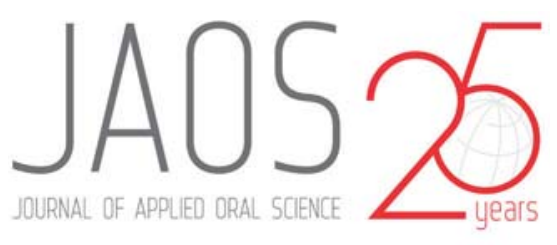

\title{
Physical properties and biological effects of mineral trioxide aggregate mixed with methylcellulose and calcium chloride
}

\section{Abstract}

Bin-Na LEE ${ }^{1}$

Soo-Ji CHUN ${ }^{1}$ Hoon-Sang $\mathrm{CHANG}^{1}$

Yun-Chan HWANG ${ }^{1}$

In-Nam HWANG ${ }^{1}$

Won-Mann $\mathrm{OH}^{1}$

Bin-Na LEE
Soo-Ji CHUN

Submitted: February 24, 2017 Modification: April 27, 2017

Accepted: June 02, 2017
Objectives: Methylcellulose (MC) is a chemical compound derived from cellulose. MTA mixed with MC reduces setting time and increases plasticity. This study assessed the influence of $\mathrm{MC}$ as an anti-washout ingredient and $\mathrm{CaCl}_{2}$ as a setting time accelerator on the physical and biological properties of MTA. Material and Methods: Test materials were divided into 3 groups; Group 1(control): distilled water; Group 2: $1 \% \mathrm{MC} / \mathrm{CaCl}_{2}$; Group 3: $2 \% \mathrm{MCl}$ $\mathrm{CaCl}_{2}$. Compressive strength, $\mathrm{pH}$, flowability and cell viability were tested. The gene expression of bone sialoprotein (BSP) was detected by RT-PCR and realtime PCR. The expression of alkaline phosphatase (ALP) and mineralization behavior were evaluated using an ALP staining and an alizarin red staining. Results: Compressive strength, $\mathrm{pH}$, and cell viability of MTA mixed with MC/ $\mathrm{CaCl}_{2}$ were not significantly different compared to the control group. The flowability of MTA with $\mathrm{MC} / \mathrm{CaCl}_{2}$ has decreased significantly when compared to the control $(p<.05)$. The mRNA level of BSP has increased significantly in MTA with $\mathrm{MC} / \mathrm{CaCl}_{2}$ compared to the control $(\mathrm{p}<.05)$. This study revealed higher expression of ALP and mineralization in cells exposed to MTA mixed with water and MTA mixed with $\mathrm{MC} / \mathrm{CaCl}_{2}$ compared to the control $(p<.05)$. Conclusions: MC decreased the flowability of MTA and did not interrupt the physical and biological effect of MTA. It suggests that these cements may be useful as a root-end filling material.

Keywords: Flowability. Methylcellulose. MTA. Osteogenic differentiation.

${ }^{1}$ Chonnam National University, School of Dentistry, Dental Science Research Institute, Department of Conservative Dentistry, Gwangju, Korea. 


\section{Introduction}

Since its introduction as a root-end filling material and as a root perforation repair in 1993, the use of mineral trioxide aggregate (MTA) has been expanded to many clinical applications including pulp capping, pulpotomy, and apical barrier for teeth with necrotic pulp and open apices ${ }^{5,12,13,15,26,34}$. This popularity originates from the superior biocompatibility and sealing ability of MTA to other root-end filling materials ${ }^{1,24,34}$. However, it has several disadvantages, including long setting time and poor handling characteristics because of its granular consistency ${ }^{23,33}$.

There are some studies aimed at improving the setting time and handling characteristics of MTA by using certain additives $8,16,23$. The addition of amorphous calcium lactate gluconate based liquid improves the setting time as well as clinical manageability ${ }^{16}$, however, it decreases the compressive strength of MTA $^{25}$. In another study, the addition of propylene glycol improved flowability and increased the $\mathrm{pH}$ and calcium ion release during the initial post-mixing periods, despite increasing its setting time ${ }^{11}$.

Methylcellulose (MC) is a chemical compound derived from cellulose. It is used as an additive to improve the performance of Portland cement in wet environments, as a thickener and emulsifier in several food and cosmetics, and also as a constipation treatment. Cellulose, for example, is not digestible, neither toxic, nor allergenic. An admix of $1 \% \mathrm{MC}$ and $2 \%$ calcium chloride $\left(\mathrm{CaCl}_{2}\right)$ into MTA reduced setting time and improved its moldability similarly to a reinforced zinc oxide-eugenol cement with an approximately equal compressive strength ${ }^{6}$. Moreover, the addition of $10 \% \mathrm{CaCl}_{2}$ to MTA did not alter its biologic properties regarding the formation of a mineralized barrier after pulpotomy ${ }^{8}$ and MTA mixed with calcium compounds showed a similar inflammatory response to MTA mixed with sterile water in an in vivo study ${ }^{29}$. However, there are few studies on the physical properties and biological effect of $M C$ on MTA. In addition, interaction between root-end filling materials and periradicular tissues is very important at the start and development of healing. Thus, the aim of this study was to investigate the influence of MC and $\mathrm{CaCl}_{2}\left(\mathrm{MC} / \mathrm{CaCl}_{2}\right)$ on the physical and biological properties of MTA.

\section{Material and methods}

\section{Preparation of test materials}

To prepare the additive solutions, $\mathrm{CaCl}_{2}$ (Sigma, St Louis, MO, USA) with $2 \%$ of sample weight was added to distilled water and mixed into a solution. This $\mathrm{CaCl}_{2}$ solution was placed on a hot plate whose temperature was raised to $80^{\circ} \mathrm{C}$. MC (Sigma) was added to the warm solution to obtain the concentrations to be tested ( $1 \%$ or $2 \%$ ) and was stirred until all the materials were mixed. Then, the solution was stored at $0^{\circ} \mathrm{C}$ for 20 minutes to make it thicker and stirred with a magnetic stirrer for 30 minutes to create a homogenous gel. Similar to the manufacturer's recommendations for MTA (ProRoot MTA; Dentsply Tulsa Dental, Tulsa, OK, USA), these solutions were used in a 3: 1 powder-liquid ratio and assigned to the following test groups. Group 1(control): distilled water; Group 2: $1 \% \mathrm{MC} / \mathrm{CaCl}_{2}$;

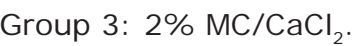

\section{Compressive strength}

The compressive strengths of the materials under test were determined according to the method recommended by the ISO $9917-1^{20}$. To prepare the specimens, polyethylene molds with $4 \mathrm{~mm}$ inner diameter and $6 \mathrm{~mm}$ height were used. The specimens were removed from the molds and a search for any air-voids or chipped edges was conducted. All defective specimens were discarded. Six samples were selected to undergo material testing, and prepared for each material test at each time interval $(n=6)$. The specimens were immersed in distilled water for 1 day, $3 \mathrm{~d}$, and $7 \mathrm{~d}$ and maintained at $37^{\circ} \mathrm{C}$. The compressive strengths were then measured using a universal testing machine (RB Model 302 ML, R\&B Inc., Korea) at a crosshead speed of $1.0 \mathrm{~mm}$ per $\mathrm{m}$. The maximum load needed to fracture each specimen was measured, and the compressive strength (C) was calculated in megapascals according to the formula:

$$
\mathrm{C}=4 \mathrm{P} / \mathrm{nD}^{2}
$$

where $\mathrm{P}$ is the maximum force applied in newtons, and $D$ is the mean diameter of the specimen in millimeters.

$\mathrm{pH}$

The $\mathrm{pH}$ was measured by using a $\mathrm{pH}$ meter (ORION STAR A211; Thermo Scientific, MA, USA) with an electrode for solid specimens (I nLab Surface; Mettler Toledo, Schwerzenbach, Switzerland). Before the 
test, the apparatus was calibrated at the standard $\mathrm{pH}$ solutions of 4.0, 7.0 and 11.0. Six specimens for each group were prepared by loading the material under test into acrylic molds with $10.0 \mathrm{~mm}$ inner diameter and $5.0 \mathrm{~mm}$ height $(n=6)$. The readings were taken at the end of the mixing and after $30 \mathrm{~m}, 1 \mathrm{~h}, 3 \mathrm{~h}, 24 \mathrm{~h}, 48 \mathrm{~h}$ and $72 \mathrm{~h}$. Between each measurement, the electrode was washed with distilled water and blot dried.

\section{Flowability}

The flowability of each group was determined as recommended by ISO $6876^{19}$. I mmediately after mixing, $50 \mu \mathrm{L}$ of each material was placed on a flat

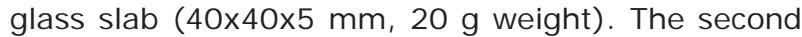
glass slab was positioned on the material followed by the addition of $100 \mathrm{~g}$ of weight after $180 \mathrm{~s}$ from the start of mixing. The weight was removed after $10 \mathrm{~m}$ of mixing. The maximum and minimum diameters of the circle formed by the material were measured. The mean diameter is considered as a measurement of the flowability only if the difference between the maximum and minimum diameters is within $1 \mathrm{~mm}$. Six tests were carried out for each material $(n=6)$.

\section{Cell culture}

Mouse periodontal ligament (mPDL) cells were used for this study and cultured in Dulbecco's modified Eagle's medium (DMEM; Invitrogen, Carlsbad, CA, USA), supplemented with $10 \%$ fetal bovine serum (FBS; Invitrogen) and $1 \%$ antibiotics ( $100 \mathrm{U} / \mathrm{mL}$ of penicillin and $100 \mu \mathrm{g} / \mathrm{mL}$ of streptomycin, Invitrogen) at $37^{\circ} \mathrm{C}$ in a humidified atmosphere containing $5 \%$ $\mathrm{CO}_{2}$. Cells used in these experiments were between passages 4 and 7 .

\section{Material extracts}

MTA samples were mixed with distilled water, 1\% $\mathrm{MC} / \mathrm{CaCl}_{2}$ and $2 \% \mathrm{MC} \mathrm{CaCl}_{2}$ in a $3: 1$ powder-liquid ratio according to the manufacturers' instructions. The materials were placed into a cylindrical polyethylene tube ( $5 \mathrm{~mm}$ in diameter and $3 \mathrm{~mm}$ in height). To attain complete setting, the samples were kept for $6 \mathrm{~h}$ at $37^{\circ} \mathrm{C}$ and $95 \%$ relative humidity. After setting, discs were exposed to ultraviolet light for $1 \mathrm{~h}$ for sterilization and transferred into 24-well culture plates. Discs were incubated in $1.5 \mathrm{~mL}$ DMEM containing $2 \%$ or $10 \%$ FBS and antibiotics at $37^{\circ} \mathrm{C}$ in a humidified atmosphere with $5 \% \mathrm{CO}_{2}$ for $24 \mathrm{~h}$. The extracts were collected and then filtered using $0.20 \mu \mathrm{m}$ filters (Minisart, Sartorius Stedim Biotech, Goettingen, Germany).

\section{Cell viability assay}

The MPDL cells were seeded into 96-well culture plates at a density of $1 \times 10^{4}$ cells per well and incubated in a growth medium (DMEM containing $10 \%$ FBS and 1\% antibiotics) for $24 \mathrm{~h}$ for adhesion. The medium was replaced with $100 \mu \mathrm{L}$ material extracts of experimental groups and incubated for $24 \mathrm{~h}$. The mPDL cells and the growth medium were used for control. To compare dose-response relationships, the material extracts were gradually diluted in the growth medium to obtain 5 concentrations $(1,1 / 2,1 / 4,1 / 10$, and $1 / 50$ ). Ten microliter of the WST reagent (EZCyTox; Daeil Lab Service Co., Seoul, Korea) was added to each well and incubated at $37^{\circ} \mathrm{C}$ for $3 \mathrm{~h}$. Optical densities were measured at $420 \mathrm{~nm}$ using a multiwell spectrophotometer (VERSAmax Multiplate Reader; Molecular Devices, Sunnyvale, CA, USA). The relative cell viability was calculated for each test material as mean percentage of the control.

\section{Reverse-transcription PCR and quantitative real-time RCR}

The MPDL cells were seeded in 6-well plates at a density of $2 \times 10^{5}$ cells per well and incubated in a growth medium for $24 \mathrm{~h}$. The growth medium was replaced with a medium containing $1 / 4$ concentration of material extracts. The untreated cells were used for control. After 1, 3, and $5 \mathrm{~d}$ in culture, the total RNA was extracted using a TRIzol reagent (Invitrogen). The purity and quantity of total RNA were determined using a spectrophotometer (Nanodrop 100; Thermo Fisher Scientific, Waltham, MA, USA). Complementary DNA was synthesized using the Maxime RT PreMix Kit (iNtRON Biotechnology, Seongnam, Korea). Each reaction consisted of an initial denaturation at $95^{\circ} \mathrm{C}$ for $1 \mathrm{~m}$ followed by a three-step cycling: denaturation at $95^{\circ} \mathrm{C}$ for $30 \mathrm{~s}$, annealing at $55^{\circ} \mathrm{C}$ for $30 \mathrm{~s}$, and extension at $72^{\circ} \mathrm{C}$ for $30 \mathrm{~s}$. After $25-30$ cycles, the reactions underwent a final extension at $72^{\circ} \mathrm{C}$ for $5 \mathrm{~m}$. The primer sequences were the following: bone sialoprotein (BSP), forward 5'-ACACTTACCGAGCTTATGAG-3' and reverse 5'-TTGCGCAGTTAGCAATAGCA-3'; and $\beta$-actin, forward 5'-TGGATGGCTACGTACATGGCTGGG-3' and reverse 5'-TTCTTTGCAGCTCCTTCGTTGCCG-3'. Each reaction was analyzed with $1.5 \%$ agarose gel electrophoresis and visualized with ethidium bromide staining. Quantitative real-time PCR was performed by using the QuantiTect SYBR Green PCR kit (Qiagen, Valencia, CA, USA). The mean cycle threshold values 
from triplicate measurements were used to determine the relative level of expression of the target gene with normalization to the endogenous control $\beta$-actin. The relative change in gene expression was analyzed by the $\Delta \Delta C T$ method $^{27}$.

\section{Alkaline phosphatase (ALP) staining}

The MPDL cells were seeded in 24-well plates at a density of $2 \times 10^{4}$ cells per well with growth medium. After $24 \mathrm{~h}$, the growth medium was changed to a medium containing $1 / 4$ concentration of material extracts and cultured for $5 \mathrm{~d}$. The cultured cells were washed with phosphate buffered saline (PBS) and fixed with $70 \%$ ethanol for $20 \mathrm{~m}$ at $4^{\circ} \mathrm{C}$. After fixation, the cells were washed 3 times with deionized water and $300 \mu \mathrm{L}$ ALP staining solution (1-Step NBT/BCIP Solution, Thermo Fisher Scientific Inc., Rockford, IL, USA) was applied per well under dark conditions for $15 \mathrm{~m}$. The stains were extracted with $10 \%(\mathrm{w} / \mathrm{v})$ ceptylpyridinium chloride (Sigma) in $10 \mathrm{mM}$ sodium phosphate for $15 \mathrm{~m}$. The ALP stain was quantified by recording the absorbance at $562 \mathrm{~nm}$ using a spectrophotometer (VERSAmax multiplate reader, Molecular Devices).

\section{Alizarin red staining}

Alizarin red staining was used to assess mineralized deposit formation. The MPDL cells were cultured with growth medium containing $1 / 4$ dilutions of material extracts for $14 \mathrm{~d}$. The cells were rinsed with PBS, and fixed with $70 \%$ ethanol for $60 \mathrm{~m}$ at $4^{\circ} \mathrm{C}$. The cells were stained with $0.5 \%$ alizarin red $(\mathrm{pH}=4.2)$ for 60 $\mathrm{m}$ at room temperature with gentle agitation. The cells were then rinsed with deionized water 5 times,

Table 1- Means and standard deviations of the compressive strengtth of test materials at various time intervals

\begin{tabular}{cccc}
\hline Group & 1 day & 3 days & $\mathbf{7}$ days \\
\hline MTA + DW & $18.88 \pm 4.53$ & $22.71 \pm 3.25$ & $20.96 \pm 4.97$ \\
MTA + 1\% MC & $19.19 \pm 3.06$ & $23.95 \pm 7.43$ & $25.40 \pm 7.03$ \\
MTA + 2\% MC & $24.19 \pm 5.46$ & $22.13 \pm 4.46$ & $22.24 \pm 4.59$ \\
\hline
\end{tabular}

rinsed with PBS for $15 \mathrm{~m}$ and air-dried. 10\% (w/v) ceptylpyridinium chloride (Sigma) in $10 \mathrm{mM}$ sodium phosphate was applied to the stained nodule and the absorbance of the supernatants was recorded at $540 \mathrm{~nm}$ using a spectrophotometer (VERSAmax multiplate reader, Molecular Devices) for quantitative assessment.

\section{Statistical analysis}

Each experiment, containing triplicate independent samples, was repeated at least twice, and qualitatively identical results were obtained. One-way analysis of variance (ANOVA) was usd followed by Tukey post hoc test to assess any differences in flowability and ALP activity and alizarin red staining. For compressive strength, $\mathrm{pH}$ and cell viability, the two-way ANOVA and the Duncan tests were used. Data from realtime PCR was analyzed with the Kruskal-Wallis and Mann-Whitney $U$ tests. The results were considered statistically significant at $p<.05$.

\section{Results}

\section{Compressive strength}

The compressive strengths of MTA mixed with $1 \%$ and $2 \% \mathrm{MC} \mathrm{CaCl}_{2}$ were not significantly different compared to MTA mixed with distilled water (Table 1). Also, there was no statistically significant difference between the time points.

$\mathrm{pH}$

The mean $\mathrm{pH}$ of all samples is in Table 2. The $\mathrm{pH}$ values of MTA mixed with $1 \%$ and $2 \% \mathrm{MC} \mathrm{CaCl}_{2}$ were not significantly different compared toMTA mixed with distilled water. Up to $3 \mathrm{~h}$, all groups showed higher $\mathrm{pH}$ values compared to the other periods, with a significant difference of $p<.05$. After $3 \mathrm{~h}$, despite decreasing, the $\mathrm{pH}$ values still remained high.

Table 2- Means and standard deviations of the $\mathrm{pH}$ of test materials at various time intervals

\begin{tabular}{|c|c|c|c|c|c|c|c|}
\hline Group & Immediately & $30 \mathrm{~m}$ & $1 \mathrm{~h}$ & $3 h$ & $24 h$ & $48 h$ & $72 h$ \\
\hline$M T A+D W$ & $12.83 \pm 0.02^{\mathrm{Aa}}$ & $12.90 \pm 0.04^{\mathrm{Aa}}$ & $12.74 \pm 0.27^{\mathrm{Aa}}$ & $11.82 \pm 1.03^{\mathrm{Aa}}$ & $10.93 \pm 0.94^{\mathrm{Ab}}$ & $9.82 \pm 0.33^{\mathrm{Ac}}$ & $9.61 \pm 0.29^{A c}$ \\
\hline $\mathrm{MTA}+1 \% \mathrm{MC}$ & $12.95 \pm 0.01^{\mathrm{Aa}}$ & $12.99 \pm 0.14^{\mathrm{Aa}}$ & $12.76 \pm 0.22^{\mathrm{Aa}}$ & $12.21 \pm 1.05^{\mathrm{Aa}}$ & $9.99 \pm 0.54^{\mathrm{Ab}}$ & $9.53 \pm 0.14^{\mathrm{Ab}}$ & $9.43 \pm 0.15^{\mathrm{Ab}}$ \\
\hline$M T A+2 \% M C$ & $12.90 \pm 0.06^{\mathrm{Aa}}$ & $12.97 \pm 0.04^{\mathrm{Aa}}$ & $12.96 \pm 0.08^{\mathrm{Aa}}$ & $12.57 \pm 0.36^{\mathrm{Aa}}$ & $10.02 \pm 0.43^{\mathrm{Ab}}$ & $9.61 \pm 0.19^{A b}$ & $9.49 \pm 0.08^{A b}$ \\
\hline
\end{tabular}

* A capital letter indicates no significant difference between test materials $(p>.05)$

* Different lowercase letters indicate significant difference between periods $(p<.05)$ 


\section{Flowability}

The results from the flowability test are shown in Figure 1. The mean diameter of group 1 (distilled water) was $12.65 \pm 1.72 \mathrm{~mm}$, of group 2 ( $1 \% \mathrm{MC}$ ) $\mathrm{CaCl}_{2}$ ) was $11.70 \pm 1.51 \mathrm{~mm}$, and of group 3 was $10.17 \pm 1.68\left(2 \% \mathrm{MC} \mathrm{CaCl}_{2}\right)$. The flowability of groups 2 and 3 decreased when compared to group 1 and we observed a statistically significant difference between group 1 and group 3.

\section{Cell viability}

The cell viability of MTA mixed with $1 \%$ and $2 \%$ $\mathrm{MC} / \mathrm{CaCl}_{2}$ was not significantly different compared to MTA mixed with water (Figure 2). However, there were statistically significant differences in concentrations. The cell viability of the control, and of 1 /50 and 1 / 10 concentrations were significantly higher compared to $1 / 4,1 / 2$ and 1 concentrations. And $1 / 4$ and $1 / 2$ concentrations had significantly higher cell viability comparedto the 1 concentration. There was no statistical difference between the tested materials. Based on this data, the $1 / 4$ concentration was retained for the following experiments.

\section{RT-PCR and quantitative real-time RCR}

To investigate the effect of MTA mixed with MC/ $\mathrm{CaCl}_{2}$ in osteogenic differentiation of MPDL cells, we evaluated the expression of BSP and the osteoblastspecific gene. As shown in Figure 3A, the expression of BSP mRNA increased in all tested groups compared to the control (treated with medium only) after $5 \mathrm{~d}$. According to the results of real-time PCR, the mRNA level of BSP increased significantly in the MTA mixed with $1 \%$ and $2 \% \mathrm{MC} \mathrm{CaCl}_{2}$ group compared to the control at day $5(p<.05)$ (Figure 3B).

\section{Mineralization effect}

We investigated the mineralization effect of MTA mixed with $\mathrm{MC} / \mathrm{CaCl}_{2}$ with ALP staining and alizarin red $S$ staining. According to the results of ALP staining (Figure $4 \mathrm{~A}$ and $\mathrm{B}$ ), MTA mixed with distilled water and $1 \%$ and $2 \% \mathrm{MC} \mathrm{CaCl}_{2}$ groups showed significant increase in ALP activity at $5 \mathrm{~d}$ compared to the control $(p<.05)$. Alizarin red staining, used to detect

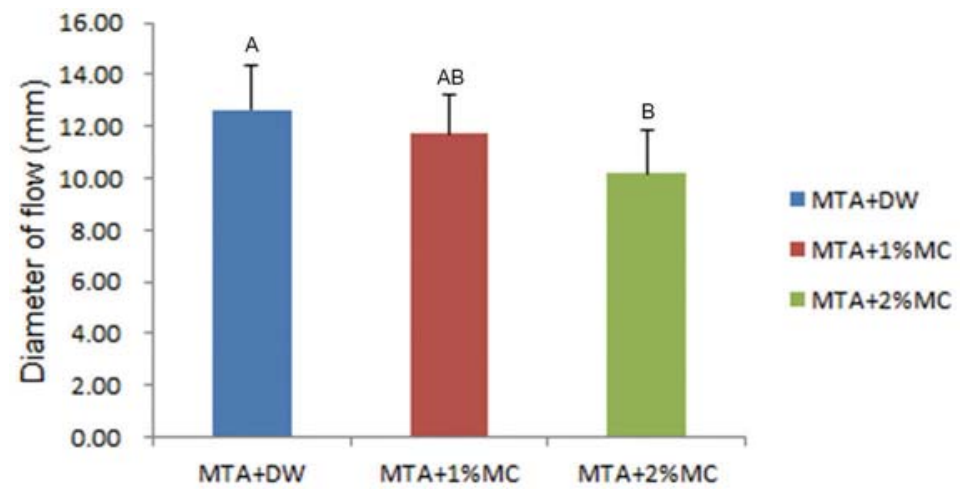

Figure 1- The flowability of test materials. The flowability of MTA mixed with $1 \%$ and $2 \% \mathrm{MC} / \mathrm{CaCl}_{2}$ decreased when compared to MTA mixed with distilled water. Different letters represent statistically significant differences between the tested materials $(p<.05)$

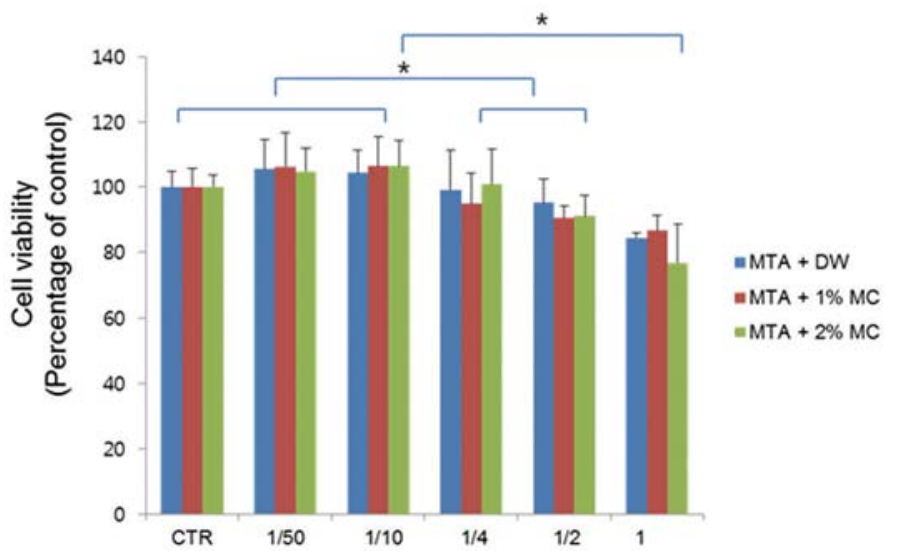

Figure 2- The cell viability of mPDL cells exposed to extracts of the test materials. The cell viability of MTA mixed with $1 \%$ and $2 \% \mathrm{MC} /$ $\mathrm{CaCl}_{2}$ was not significantly different than that of MTA mixed with water. The cell viability of the control, and of $1 / 50$ and $1 / 10$ concentrations was significantly higher than that for $1 / 4,1 / 2$ and 1 concentrations with the same material. And $1 / 4$ and $1 / 2$ concentrations had significantly higher cell viability than the 1 concentration $\left({ }^{*} p<.05\right)$ 
(A)

Day 1

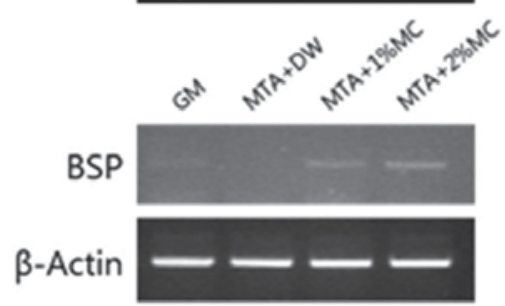

(B)
Day 5

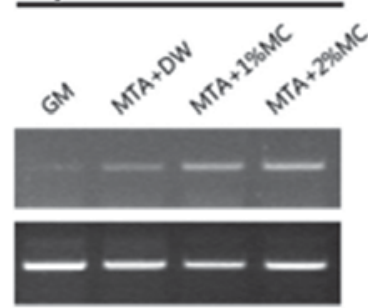

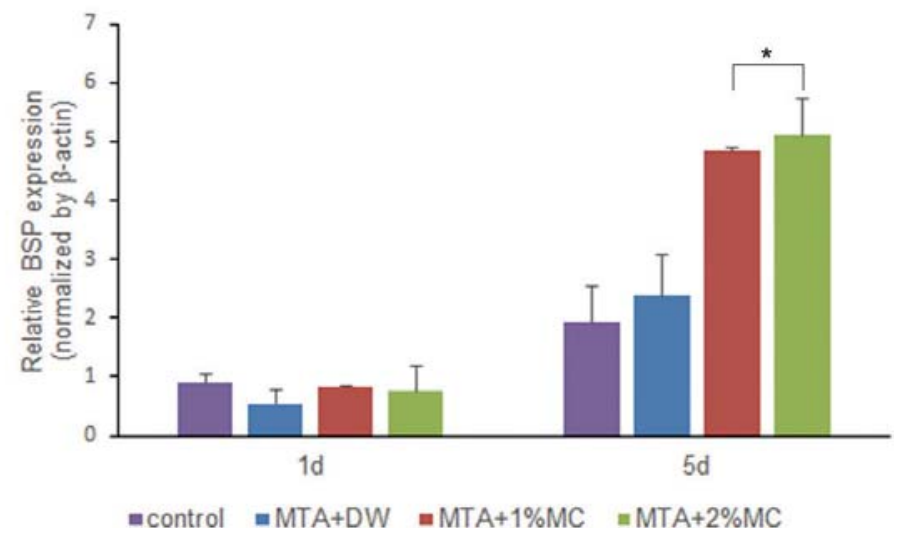

Figure 3- Expression profiles of bone sialoprotein (BSP) during osteogenic differentiation by test materials in mPDL cells assayed via RTPCR and quantitative real-time PCR. (A) RT-PCR results. (B) The relative expression of BSP genes normalized against a housekeeping gene ( $\beta$-actin). The mRNA level of osteogenic gene increased in the MTA mixed with $1 \%$ and $2 \% \mathrm{MC} \mathrm{CaCl}_{2}$. ${ }^{*} \mathrm{p}<.05$, compared to the control

mineralized nodule formation, showed all experimental groups increased mineralization significantly $(p<.05)$ (Figure 4C and D).

\section{Discussion}

MTA consists of fine hydrophilic particles of calcium silicates $^{21}$. Despite MTA having many favorable properties, it has some disadvantages. It is difficult to mix MTA to an ideal consistency, to deliver it to the operation site, and to condense it densely. Several research has focused on these limitations ${ }^{10,17,23,25,35}$. Therefore, the objectiveof this study was to evaluate the physical and biological effects of MC that, when added to MTA, could improve its handling characteristics.

The compressive strengths of MTA mixed with

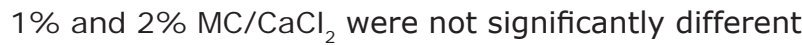
compared to MTA mixed with distilled water. These values are similar to those reported by a previous study $^{23}$. Compressive strength is an important factor to consider when placing a filling material in a cavity that bears pressure. Because $M C$ does not influence the compressive strength of MTA, it can be used with MTA for perforation repair as well as root-end fillings. There were some studies on antimicrobial activity of MTA. They insisted that alkaline $\mathrm{pH}$ played an important role for this property $2,4,14,30$. In this study, the $\mathrm{pH}$ values of MTA mixed with $1 \%$ and $2 \% \quad \mathrm{MC} / \mathrm{CaCl}_{2}$ were not significantly different compared to MTA mixed with distilled water. This $\mathrm{pH}$ stability at alkaline conditions may not affect the antimicrobial properties of the modified MTA system. MC consists of nonionic watersoluble cellulose ether and increases viscosity and dispersion resistance ${ }^{3}$. MC decreased the flowability of MTA significantly in this study. We first thought that MC improved the handling characteristics of MTA.

Considering it contains various stem cells ${ }^{31}$, we used the MPDL cell for several biological experiments such as cell viability, RT-PCR and mineralization assay of root-end filling materials in this study. The cell viability of MTA mixed with $1 \%$ and $2 \% \mathrm{MC} /$ $\mathrm{CaCl}_{2}$ was not significantly different compared to MTA mixed with water. However, the cell viability of experimental groups in higher concentrations (1/4, $1 / 2$, and 1 concentration) was significantly lower than 
A

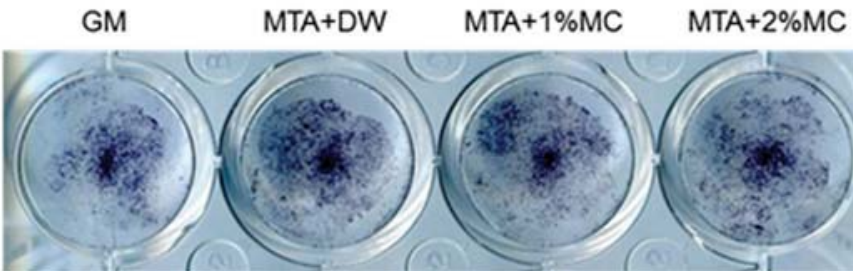

B

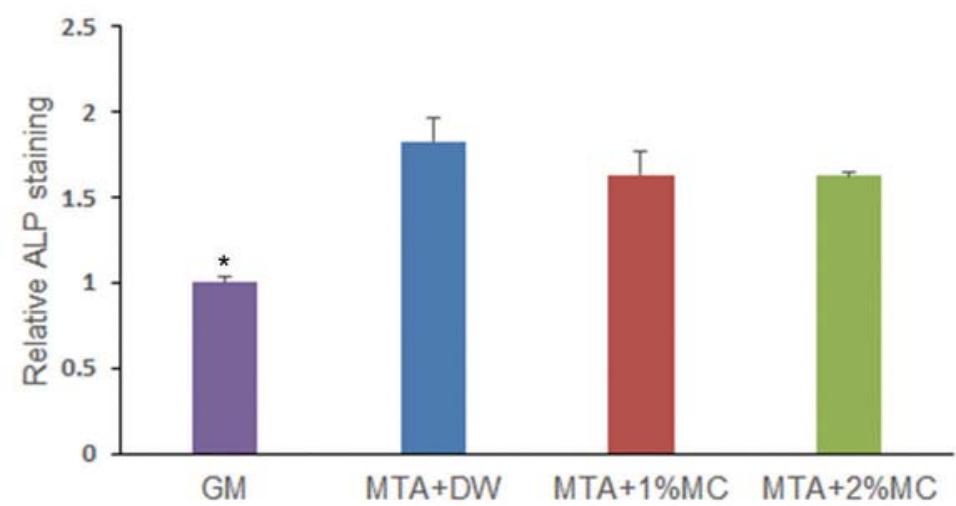

C

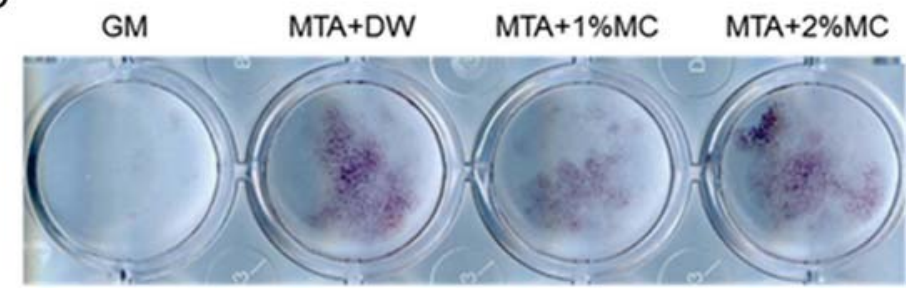

D

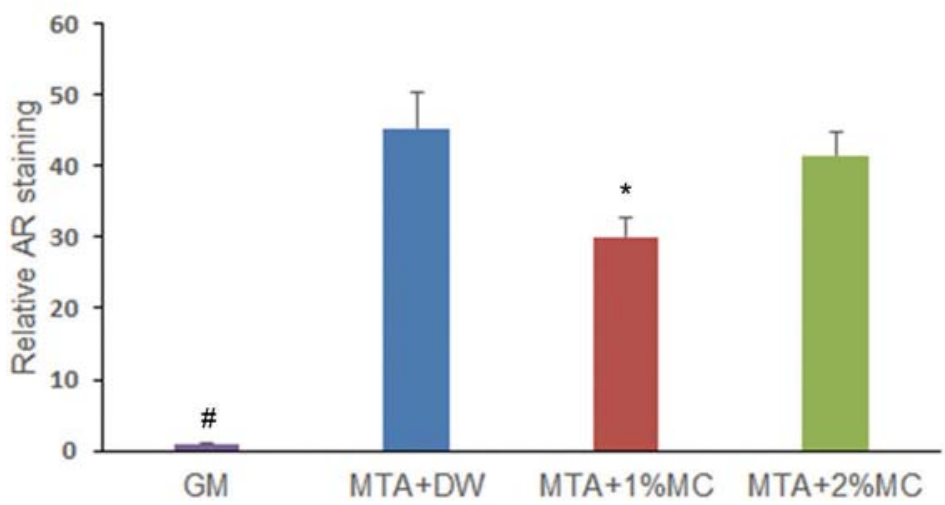

Figure 4- Alkaline phosphatase (ALP) staining and alizarin red staining in $\mathrm{mPDL}$ cells exposed to extracts of the tested materials. (A) Phenotype expression of ALP during osteogenic differentiation by the tested materials in mPDL cells at $5 \mathrm{~d}$. (B) Quantified data. (C) Matrix mineralization of mPDL cells observed by staining calcium deposits in the extracellular matrix after $14 \mathrm{~d}$. (D) Quantified data. We observed a higher ALP expression and mineralization in cells exposed to tested materials comparatively with the control. * $p<.05$, compared to the control

the groups in lower concentrations (control, 1/50, and $1 / 10$ concentration). Kang, et al. ${ }^{22}$ (2013) reported that MTA mixed with calcium chloride showed lower biocompatibility than MTA mixed with water. Therefore, calcium chloride added with MC might contribute to the lower cell viability of experimental groups in high concentrations. The differentiation of progenitor cells into osteoblast-like cells is critical in the healing process, and promoting differentiation is required when considering a biomaterial as a root-end filling material. BSP is the major phosphorylated protein of mammalian bone and its use has been suggested at the startof mineralization ${ }^{7,18}$. Consideringit is believed that this protein has a specific role in mediating the initial stage of mineralization ${ }^{9}$, increased BSP expression suggests the differentiation of several cells into osteoblasts. In this study, the expression of BSP mRNA increased in all tested groups compared 
to the medium-only treated group in RT-PCR. These results suggest that MTA stimulates the osteogenic differentiation of MPDL cells and MC did not interrupt the biological effect of MTA. Considering ALP and alizarin red staining data, it seems that MTA and MTA mixed with $\mathrm{MC} / \mathrm{CaCl}_{2}$ stimulate the expression of ALP and the formation of calcium nodules in MPDL cells. These results also suggest that MTA stimulates the mineralization effect ${ }^{28,32}$ of $\mathrm{mPDL}$ cells and MC did not interrupt the mineralization effect of MTA.

These findings support the hypothesis that MC decreased the flowability of MTA and did not interrupt the physical and biological effects of MTA. However, there is need for further studies to clarify the detailed mechanism of how MTA and MTA mixed with $\mathrm{MC} / \mathrm{CaCl}_{2}$ induce osteogenic differentiation of MPDL cells.

\section{Conclusion}

MC decreased the flowability of MTA and did not interrupt its physical and biological effects, whichsuggests that these cements can be useful as root-end filling materials.

\section{Acknowledgements}

Bin-Na Lee and Soo-Ji Chun contributed equally to this work. The authors declare no conflicts of interest inthis study. This study was supported by a grant (CRI 16025-1) from the Chonnam National University Hospital Biomedical Research Institute and the National Research Foundation of Korea (NRF) grant funded by the Korea government (MSIP) (No. 2016R1C1B1012703).

\section{References}

1- Adamo H, Buruiana R, Schertzer L, Boylan R. A comparison of MTA, Super-EBA, composite and amalgam as root-end filling materials using a bacterial microleakage model. Int Endod J. 1999;32(3): 197-203.

2-Al-Hezaimi K, Al-Shalan TA, Naghshbandi J, Simon JH, Rotstein I. MTA preparations from different origins may vary in their antimicrobial activity. Oral Surg Oral Med Oral Pathol Oral Radiol Endod. 2009; 107(5): e85-8.

3-Andersson G, Johansson G, Attström R, Edwardsson S, Glantz PO Larsson K. Comparison of the effect of the linseed extract Salinum ${ }^{\circledR}$ and a methyl cellulose preparation on the symptoms of dry mouth. Gerodontology. 1995; 12(1): 12-7

4-Asgary S, Kamrani FA. Antibacterial effects of five different root canal sealing materials. J Oral Sci. 2008;50(4):469-74.
5-Barrieshi-Nusair KM, Qudeimat MA. A prospective clinical study of mineral trioxide aggregate for partial pulpotomy in cariously exposed permanent teeth. J Endod. 2006;32(8):731-5.

6-Ber BS, Hatton JF, Stewart GP. Chemical modification of ProRoot MTA to improve handling characteristics and decrease setting time. J Endod. 2007; 33(10): 1231-4.

7-Bianco P, Fisher LW, Young MF, Termine JD, Robey PG. Expression of bone sialoprotein (BSP) in developing human tissues. Calcif Tissue Int. 1991;49(6): 421-6.

8- Bortoluzzi EA, Broon NJ, Bramante CM, Consolaro A, Garcia RB, Moraes IG, et al. Mineral trioxide aggregate with or without calcium chloride in pulpotomy. J Endod. 2008;34(2):172-5.

9-Chen J, Shapiro HS, Sodek J. Developmental expression of bone sialoprotein mRNA in rat mineralized connective tissues. J Bone Miner Res. 1992; 7(8): 987-97.

10-Ding SJ, Kao CT, Shie MY, Hung C, Huang TH. The physical and cytological properties of white MTA mixed with $\mathrm{Na}_{2} \mathrm{HPO}_{4}$ as an accelerant. J Endod. 2008; 34(6): 748-51.

11- Duarte MA, Aguiar KA, Zeferino MA, Vivan RR, Ordinola-Zapata R, Tanomaru-Filho M, et al. Evaluation of the propylene glycol association on some physical and chemical properties of mineral trioxide aggregate. Int Endod J. 2012;45(6):565-70.

12-El Meligy OA, Avery DR. Comparison of apexification with mineral trioxide aggregate and calcium hydroxide. Pediatr Dent. 2006; 28(3): 248-53.

13-El Meligy OA, Avery DR. Comparison of mineral trioxide aggregate and calcium hydroxide as pulpotomy agents in young permanent teeth (apexogenesis). Pediatr Dent. 2006; 28(5):399-404

14-Eldeniz AU, Hadimli HH, Ataoglu H, Ørstavik D. Antibacterial effect of selected root-end filling materials. J Endod. 2006;32(4):345-9.

15-Ford TR, Torabinejad M, Abedi HR, Bakland LK, Kariyawasam SP. Using mineral trioxide aggregate as a pulp-capping material. J Am Dent Assoc. 1996; 127(10):1491-4.

16- Hsieh SC, Teng NC, Lin YC, Lee PY, Ji DY, Chen CC, et al. A novel accelerator for improving the handling properties of dental filling materials. J Endod. 2009; 35(9): 1292-5.

17-Huang TH, Shie MY, Kao CT, Ding SJ. The effect of setting accelerator on properties of mineral trioxide aggregate. J Endod. 2008;34(5):590-

18-Hunter GK, Goldberg HA. Nucleation of hydroxyapatite by bone sialoprotein. Proc Natl Acad Sci U S A. 1993;90(18):8562-5.

19-International Organization for Standardization. ISO 6876 . Dentistry: root canal sealing materials. Geneva: The Organization; 2010.

20-International Organization for Standardization. ISO 9917-1 Dentistry: water-based cements. part 1: powder/liquid acid-base cements. Geneva: The Organization; 2007.

21-Islam I, Chng HK, Yap AU. Comparison of the physical and mechanical properties of MTA and Portland cement. J Endod. 2006; 32(3): 193-7.

22- Kang JY, Lee BN, Son HJ, Koh JT, Kang SS, Son HH, Chang HS, et al. Biocompatibility of mineral trioxide aggregate mixed with hydration accelerators. J Endod. 2013;39(4):497-500.

23-Kogan P, He J, Glickman GN, Watanabe I. The effects of various additives on setting properties of MTA. J Endod. 2006;32(6):569-72. 24-Koh ET, McDonald F, Ford TR, Torabinejad M. Cellular response to mineral trioxide aggregate. J Endod. 1998;24(8):543-7.

25- Lee BN, Hwang YC, J ang J H, Chang HS, Hwang IN, Yang SY, et al. Improvement of the properties of mineral trioxide aggregate by mixing with hydration accelerators. J Endod. 2011;37(10): 1433-6.

26-Lee SJ, Monsef M, Torabinejad M. Sealing ability of a minera trioxide aggregate for repair of lateral root perforations. J Endod. 1993; 19(11):541-4 
27-Livak KJ, Schmittgen TD. Analysis of relative gene expression data using real-time quantitative PCR and the $2-\triangle \triangle C T$ method. Methods. 2001;25(4): 402-8.

28-Matsumoto S, Hayashi M, Suzuki Y, Suzuki N, Maeno M, Ogiso B. Calcium ions released from mineral trioxide aggregate convert the differentiation pathway of $\mathrm{C} 2 \mathrm{C} 12$ cells into osteoblast lineage. J Endod. 2013;39(1):68-75.

29-McNamara RP, Henry MA, Schindler WG, Hargreaves KM. Biocompatibility of accelerated mineral trioxide aggregate in a rat model. J Endod. 2010;36(11): 1851-5.

30-Parirokh $\mathrm{M}$, Torabinejad $\mathrm{M}$. Mineral trioxide aggregate: a comprehensive literature review-part I: chemical, physical, and antibacterial properties. J Endod. 2010;36(1): 16-27.

31-Seo BM, Miura M, Gronthos S, Bartold PM, Batouli S, Brahim J, et al. Investigation of multipotent postnatal stem cells from human periodontal ligament. Lancet. 2004; 364(9429): 149-55.
32- Seo MS, Hwang KG, Lee J, Kim H, Baek SH. The effect of mineral trioxide aggregate on odontogenic differentiation in dental pulp stem cells. J Endod. 2013;39(2):242-8.

33-Torabinejad M, Hong C, McDonald F, Ford TP. Physical and chemical properties of a new root-end filling material. J Endod. 1995;21(7):34953.

34-Torabinejad M, Watson T, Ford TP. Sealing ability of a mineral trioxide aggregate when used as a root end filling material. J Endod. 1993; 19(12): 591-5.

35-Wiltbank KB, Schwartz SA, Schindler WG. Effect of selected accelerants on the physical properties of mineral trioxide aggregate and Portland cement. J Endod. 2007;33(10): 1235-8. 